\title{
Classical View on Bhasma as Chief Formulation of Rasashastra: An
}

\section{Ayurveda Review}

Available online at www.hjhs.co.in

\section{REVIEW ARTICLE}

\section{Dayanand Dattatraya Ovar*, a , Ujwala Murlidhar Katole ${ }^{\mathrm{b}}$, Ganesh Sakharam}

\section{Deshmukh $^{c}$, Monish Maruti Shinde ${ }^{d}$}

${ }^{a}$ Professor, Dept of Rasashastra and Bhaishajya Kalpana, Dr R N Lahoti Ayurved College, Sultanpur, Dist. Buldhana, India.

${ }^{b}$ Reader, Dept of Prasuti Tantra Evum Strirog, Dr R N Lahoti Ayurved College, Sultanpur,

Dist. Buldhana, India.

${ }^{\mathrm{c}}$ Reader, Dept of Rasashastra and Bhaishajya Kalpana, Dr Vedprakash Patil Ayurved

College, Jalna, Dist. Jalna, India.

${ }^{\mathrm{d}}$ Lecturer, Dept of Rasashastra and Bhaishajya Kalpana, Dr Vedprakash Patil Ayurved

College, Jalna, Dist. Jalna, India.

DOI 10.22270/hjhs.v6i3.103

\begin{abstract}
Minerals and metals based drugs possess important therapeutic potential and preparation of such medicines described in Rasashastra which deals with minerals and metals based formulations. The processing techniques related to the preparation of these medicines are very specific to make these drugs nontoxic and efficacious. Shodhana means purification and Marana means incineration/calcinations are main procedures associated with the preparation of RasaAushdhis. Bhasmas are important preparation of this category which is considered as herbo-metallic preparation and description of Bhasma Kalpana is found in Ayurveda Samhitas during Arsha Sampradaya. These herbomineral/metallic formulations (Bhasma) mainly prepared by various steps of purification, grinding, mixing, heating, incineration and size reduction, etc. These drugs possess advantages of palatability, low dosing frequency, high potency, good bioavailability, optimum absorption and wide range of therapeutic spectrum. Bhasma not only used for therapeutic purpose but also advised for promoting general health and rejuvenating effects. Makshika bhasma, Swarna bhasma, Abhrak bhasma, Louha bhasma and Tamra bhasma, etc. are commonly used Bhasma preparation indicated for many pathological conditions including skin diseases, digestive ailments, sexual disorders, asthma and infections, etc.
\end{abstract}

Keywords: Ayurveda, Rasashastra, Bhasma, Shodhana, Marana

\section{Introduction}

The natural substances have been used extensively for therapeutic purpose and in this regard Ayurveda suggested herbs, metals and mineral based preparations for treating several health ailments. The Bhasma is one such type formulation prepared from mental/mineral after their detoxification. Bhasma mainly prepared by incinerating metals and used as nanomedicines. The process involved in the preparation of Bhasma convert toxic metals into not-toxic biologically compatible form. The therapeutic effect and optimum pharmacokinetic properties of Bhasma can be attributed to their small particle size which facilitates easy transportation of active ingredients to the specific target sites. (1-5)

Rasa Shastra described various methods for the preparation of Bhasma including Shodhana, Marana, Amritikarana, Satavapatana and Samskara, etc. Some intermediate steps Bhavana, Chakrikanirmana and Saravasamputikarana, etc. also play important 
role in the preparation of Bhasma. These preparatory methods impart high therapeutic value in Bhasma and convert non compatible form of metal or mineral into biological compatible form.

Bhasma Kalpana provides higher efficacy in lower dosing, good palatability, and optimum absorption in biological system, stability and ability to cure chronic health ailments. Bhasmikaran involves certain Samskaras by which toxic or noncompatible form of mineral/metal get converted into non-toxic and compatible form with retention or enhancement of therapeutic potency. Bhasmikaran give micronized size of ingredients due to which active drug get absorbed easily and passes through minute channels of body. The one of the important preparatory step of Bhasmas is treatment of metallic/mineral preparations with herbal juices or decoction for certain period of time. This process helps to detoxify mental/minerals used for Bhasmas preparation and selection of plant juices and decoction merely depends of types of Bhasmas. (2-4)

\section{Method of Preparation}

* Pre treatment

This was done by performing Shodhana (purification) procedure to detoxify harmful substances.

* Main

Procedure

(Incineration/Calcination)

Incineration or calcination considered as main procedure which described as Marana in Ayurveda, this involves some intermediate steps such as; Bhavana, Hakrikanirmana and Sarava-Samputikarana.

* Post Procedure

The Lohitikarana and Amritikarana are process which employed as post procedure after preparation of Bhasma, these processes improves quality of Bhasma preparation.

\section{Role of Specific Procedures in Preparation of Bhasma:}

Sodhana helps in purification this can be done using herbal extract, juices and decoction.

Bhavana provides wetness since it performed as wet trituration.

Chakrikanirmana used for pelletization purpose, it is important for proper dosing formulation. Chakrikanirmana facilitates homogenous heating since proper transmission of heat occurs from periphery to core of Chakrika.

Aatapa Shoshana helps to dry pellets.

Saravasamputikarana brings sealing of casserole. This process protects material from contamination, avoids loss during heating treatment, facilitate homogeneous atmosphere and prevents escape of volatile material.

\section{Putapaka Bhasma}

These are Bhasma which prepared by Putapaka method in which minerals or metals subjected for Shodhana, Bhavana and Marana. Metals or minerals converted to coarse powder and subjected to purification (Shodhana), that after metals or minerals heated to red hot and treated with particular liquid media for specific times. Thereafter Shodhita substance mixed with particular drugs for Marana purpose and Bhavana is given using specific drug for particular time period. Chakrikas prepared after completion of Bhavana and sealed in crucible with mud smeared clothes. Sharava Samputa is subjected for heating using Putas for particular time period. These procedures repeated for many times to get desired quality of final Bhasma formulation. The metals possess low melting point like; tin, zinc and lead require an intermediate procedure called Jarana which is performed between Shodhana and Bhavana procedure. Jarana involves melting and mixing of metals with some 
plant substance, that after rubbed till to get powder form. (5-7)

\section{Kupipakwa Bhasma}

Kupipakwa Bhasma is prepared by utilizing various processes i.e.; Shodhana, Kajjali Nirmana, Bhavana and Kupipakwa. Metals is subjected to form amalgam with mercury after Shodhana procedure and then mixed with purified sulphur then triturated till to get black fine powder which is termed as Kajjali. This Kajjali is triturated with particular liquid media for certain period of time. Dry mixture filled in Kachkupi covered with seven layers of mud smeared cloth. The container subjected to Vaaluka Yantra for specific time period, Bhasma is collected from the bottom of Kachkupi (bottle) after its break down. (7-10)

\section{Bhasma Qualities and Bhasma Pariksha}

Bhasma should possess some properties and quality standards as depicted in Figure 1, these qualities of Bhasma can be evaluated by some Pariksha.

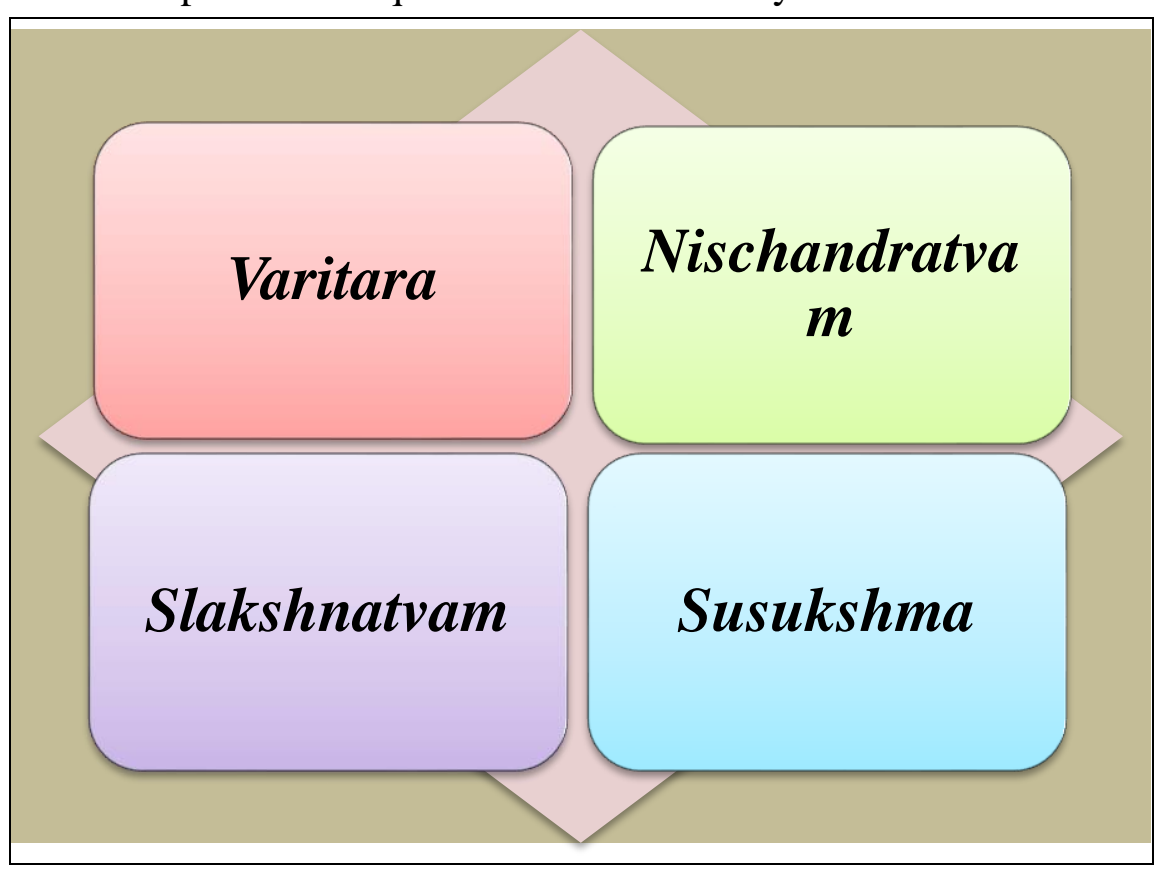

Figure 1. Desirable properties of Bhasma

Bhasma should possess specific colour, alteration in specific colour indicates improper formation of Bhasma.

Bhasma should possess quality of Nischandratvam since after proper incineration luster of metal lost. Bhasma when observed in bright sunlight, it must be Nischandra to give desired quality and potency.

Bhasma offers Varitara properties based on the law of surface tension. When Bhasma is sprinkled on stagnant water then Bhasma should float on water surface. This test indicates lightness and fineness of Bhasma.
Rekhapurnatva is another property of Bhasma which used to confirm fineness of Bhasma particles which can fill lines of finger tips when rubbed in between finger and thumb.

Bhasma should possess Slakshnatvam which is sensation produced by simple touch with finger tips.

Susukshma is very important quality of Bhasma, Sukshma Bhasma absorbed easily and possess fineness and lightness.

Gatarasatvam is another typical quality of Bhasma, as per this criterion particular types of Bhasma should possess characteristic taste. 
Apunarbhavata is one of the properties of Bhasma which indicates incapability of final Bhasma formulation to regain original metallic form.

\section{Conclusion}

Bhasma is concept of nanotechnology in which drug particle size reduces to micronized or nono-sized form to get quick absorption and easy assimilation of drug inside the body. Shodhana and Marana are important procedures involved in the preparation of Bhasma; these processes convert metallic formulation into non-toxic, absorbable, easily digestible and biological compatible form with desired therapeutic potency. Bhasmas offers Rasayana, Yogavahi, immunomodulatory, anti-aging and rejuvenating effects. Nischandratvam, Varitara, Rekhapurnatva, Susukshma, Gatarasatvam and Apunarbhavata, etc. are common properties of Bhasma. Bhasma not only used for therapeutic purpose but also helps to restore normal physiological functioning of body. Bhasma prepared by specific method with lot of expertise therefore care should be taken during preparation of Bhasma.

\section{Acknowledgements}

Authors are very thankful to Himalayan Journal of Health Sciences for publishing our article.

Financial Disclosure statement: The author received no specific funding for this work.

\section{Conflict of Interest}

The authors declare that there is no conflict of interest regarding the publication of this article.

\section{References}

1. Rastogi S. Building bridges between Ayurveda and Modern Science.2010; 41-46.

2. Sharma $\mathrm{R} K$ \& Dash B. Agnivesh'sCharakaSamhita, vol. 3, Chaukhamba Sanskrit Series Office, Varanasi.2000; 43-44
3. Mishra S, AyurvediyaRasashastra, ChaukhambaOrientalia, Varanasi. Revised 2011; 47, 93.

4. Kulkarni DA. Rasa RatnaSamucchaya, Meharchand Publications, New Delhi. 1998; 198.

5. Shastri K N. Sadanand Sharma's Rasataringini, New Delhi: Motilal Banarasidas Publications. 2000; 15, 228.

6. Karisnashastri, editor. 'Nighantu Ratnaakara', Part-1.Mumbai (India): Nirnaya sagar Press; 1936.

7. Shastri Brahmshankar. editor. 'YogaratnakarPoorwaardha'. Second edition. Varanasi (India): Chowkhambha Sanskrit Series Office; 1973. p. 151. Anonymous.

8. The Ayurvedic Pharmacopoeia of India. New Delhi: Ministry of Health and Family Welfare, Govt. of India; 1978. Anonymous.

9. Vaidya Yadavji Trikamji Acharya, Rasamrita with English commentary by Dr. damodarjoshi and G.prabhakar Rao, Chaukhambha Sanskritabhawan, Varanasi, $1^{\text {st }}$ edition, Appendix - 1; 1998. p.253.

10. Kaviraj Umesh Chandra Gupta, Vaidyak Sabda Sindhu compile by Sri nagendranath Sen. 3rd edition. Varanasi: chaukhambhaorientialia; 1983. 